\title{
Description of Enchytronia pygmaea sp. n. (Enchytraeidae, Clitellata), a very small enchytraeid in European soils
}

\author{
U. GRAEFE ${ }^{1} \&$ R. M. SCHMELZ $Z^{2,3}$ \\ ${ }^{1}$ Ulfert Graefe, IFAB Institut für Angewandte Bodenbiologie GmbH, Tornberg 24a, 22337 Hamburg, Germany \\ ${ }^{2}$ Rüdiger M. Schmelz, ECT Oekotoxikologie GmbH, Böttgerstrasse 2-14, D-65439 Flörsheim, Germany \\ ${ }^{3}$ Universidad de A Coruña, Fac. Ciencias, GIBE, Grupo de Investigación en Biología Evolutiva, CICA, \\ As Carballeiras s/n, Campus de Elviña, 15071 A Coruña, Spain
}

\begin{abstract}
A new and very small European species of terrestrial enchytraeids is described, Enchytronia pygmaea sp. nov. (Enchytraeidae, Oligochaeta). It differs from all enchytraeids known so far in the chaetal pattern: lateral bundles have 2 chaetae from segment II to V, 0 from segment VI to XII-XV, and only 1 chaeta in lateral postclitellar bundles; ventral bundles have 2 chaetae. A further peculiarity is the presence of only 1 pair of preclitellar nephridia. The species must be considered as widespread as it is recorded here from 17 different localities distributed over seven European countries ranging from the Atlantic to the Mediterranean zone.
\end{abstract}

Keywords. New species, Oligochaeta, Annelida, soil biodiversity, taxonomy.

\section{INTRODUCTION}

A new and very small species of Enchytraeidae is described. It was discovered in the course of various large-scale sampling campaigns carried out in Europe during the last 30 years. The species must be considered widespread as it is recorded here from 17 different localities distributed over seven European countries ranging from the Atlantic to the Mediterranean zone. It is easily identified due to a chaetal pattern that has hitherto not been found in any species of enchytraeids.

\section{MATERIAL AND METHODS}

Soil samples were extracted for enchytraeids, using either cold or hot wet extraction. Enchytraeids were identified and investigated in vivo. A representative sample of specimens was fixed in hot Bouin's fluid, stained, and whole-mounted. Other specimens from several localities, the type locality included, were preserved in $96 \%$ or $100 \%$ ethanol, for future DNA sequencing. Mode of description follows Schmelz \& Collado (2010). Geographical coordinates are expressed in decimal degrees, with southern latitudes and western longitudes given as negative numbers (GPS coordinates). "BDF" refers to permanent soil monitoring sites in Germany ("Boden-Dauerbeobachtungs-Flächen"). Specimens found by the second author were extracted from soil samples that had been taken by other workers and been sent to him.

\section{RESULTS}

\section{Enchytronia pygmaea sp. nov.}

(Figures 1-2)

Material examined. Holotype. ZMH OL 14530, adult specimen, stained whole mount; Germany, city of Hamburg, urban lawn Amsinckpark, German permanent soil monitoring site (BDF$\mathrm{HH}), 53.36719 ; 9.56378,54 \mathrm{~m}$ asl, $\mathrm{pH}\left(\mathrm{CaCl}_{2}\right)$ 4.3, leg. U. Graefe, 29 IV 2013.

Paratypes. ZMH OL 14531-35, 5 specimens, adult, stained whole mounts, same data as holo- 
type. ZMH OL 14536, 10 specimens, preserved in $96 \%$ ethanol, from type locality; leg. U. Graefe, 26 IV 2016.

Further material. Germany, type locality: 10 specimens, preserved in $96 \%$ ethanol, from type locality; leg. U. Graefe, 26.IV.2016. 139 specimens, mostly adult, extracted from soil samples of type locality, leg. U. Graefe, 20.X.1992 and 5.X.2012, not preserved.

Germany, other localities: 5 specimens, adult, stained whole mounts: North Rhine-Westphalia, Lippetal/Lippborg (project "Vergleichsuntersuchungen Alternativer Landbau" der Landesanstalt für Ökologie), 51.39546; 8.02009, arable land, sandy soil, pH 6.0-6.4; leg. U. Graefe, 6.V.1986. Further specimens from same locality investigated in vivo 1986-1989, not preserved. - 1 specimen, adult, Schleswig-Holstein, BDF-SH 23 Bokhorst (permanent soil monitoring site), 54.03473; 9.24003, arable land, sandy soil, $\mathrm{pH}\left(\mathrm{CaCl}_{2}\right) 5.8$; leg. U. Graefe, 21.V.1996, not preserved. - 16 specimens, adult, Schleswig-Holstein, BDF-SH 26 Bad Bramstedt (permanent soil monitoring site), 53.55297; 9.55244, grassland, sandy soil, $\mathrm{pH}\left(\mathrm{CaCl}_{2}\right)$ 4.9-5.6; leg. U. Graefe, 29.XI.1998 and 2.XI.2005, not preserved. -1 specimen, adult, Brandenburg, Komturei Lietzen (ZALF field trial reduced tillage), 52.29451; 14.21344, $48 \mathrm{~m}$ asl, arable land, sandy soil, $\mathrm{pH}(\mathrm{KCl}) 5.1$; leg. U. Graefe, 1.XI.2005, not preserved. -2 specimens, adult, Schleswig-Holstein, BDF-SH 09 Schuby (permanent soil monitoring site), 54.32087; 9.26005, $15 \mathrm{~m}$ asl, arable land, sandy soil, $\mathrm{pH}$ $\left(\mathrm{CaCl}_{2}\right)$ 5.3; leg. U. Graefe, 4.XI.2009, not preserved. -2 specimens, adult, Brandenburg, Müncheberg (ZALF permanent field trial V 140), 52.31018; 14.07192, arable land, sandy soil; leg. U. Graefe, 13.X.2010 and 19.IX.2013, not preserved. -4 specimens, adult, Schleswig-Holstein, BDF-SH 24 Bornhöved (permanent soil monitoring site), 54.32087; 9.26005, $38 \mathrm{~m}$ asl, arable land, sandy soil, $\mathrm{pH}\left(\mathrm{CaCl}_{2}\right) 5.4$; leg. U. Graefe, 25.IX.2015, not preserved. - 22 specimens, adult, Schleswig-Holstein, BDF-SH 22 Hindorf (permanent soil monitoring site), 53.59597; 9.08497, $20 \mathrm{~m}$ asl, grassland, sandy soil, pH $\left(\mathrm{CaCl}_{2}\right)$ 4.7; leg. U. Graefe, 20.X.2016, not preserved. - 1 specimen, juvenile, stained whole mount: Naturpark Eifel (Natural Reserve), near Erkensruhr, 50.54022; 6.33821, $508 \mathrm{~m}$ asl, old-growth beech forest on brown soil, $\mathrm{pH} 3.29$, R.M. Schmelz (project Edaphobase II) X.2014. Six further specimens from the same and an adjacent site, investigated in vivo, not preserved.

Estonia: 14 specimens, adult, Tartu County, Kaagvere (research area UA-II), 58.20272; $26.54215,45 \mathrm{~m}$ asl, mixed pine-spruce forest, loamy sand on sandy loam, WRB soil classification Dystric Albic Glossic Fragic Retisol, $\mathrm{pH}$ (KCl) 4.3; leg. U. Graefe, 28.VIII.2012, not preserved.

Denmark: Three specimens, 2 subadult, 1 juvenile, stained whole mounts: Jutland, Foulum, 56.483; 9.567, $53 \mathrm{~m}$ asl, experimental grassland of Arhus University; leg. R.M. Schmelz, 12.V.2011. Four further specimens collected from same site, two at same date, two in X.2010, not preserved.

The Netherlands: Three specimens, adult, in 100\% ethanol: Dennenkamp, 2.028611; 5.800556, $50 \mathrm{~m}$ asl, extensively managed grassland (project EcoFINDERS), pH 5.4-5.6; leg. R.M. Schmelz, 26 XII 2011. Further 71 specimens, not preserved. Further 12 specimens from an adjacent grassland site (Nieuw Reemst, 52.042500; 5.774722, pH 4.6), not preserved.

France: One specimen, adult: Pays de la Loire, Dép. Vendée, 46.758333; -1.867194, $18 \mathrm{~m}$ asl, small Atlantic oak forest plot (80x100 m, $9 \mathrm{~km}$ to the coast, Quercus robur) on loamy sand, $\mathrm{pH}$ data unavailable (project EcoFINDERS), RMQS site ("Réseau de Mesures de la Qualité des Sols", French Monitoring Network for Soil Quality); leg. R.M. Schmelz, 11.III.2013. Further 6 specimens from same locality, not preserved. -1 specimen, stained whole mount: Auvergne-Rhône-Alpes, Dép. Cantal, 45.10875; 2.530472, $944 \mathrm{~m}$ asl, steep, south-exposed mountain grassland on clay loam, pH data unavailable (project EcoFINDERS), RMQS site; leg. R.M. Schmelz, 7.I.2013. 
Italy: Three specimens, adult, stained whole mounts: 2 specimens, adult, in 100\% ethanol; Sardinia, Berchidda, 40.822920; 9.279786 (2 sites within a radius of ca. $50 \mathrm{~m}$ ), $335 \mathrm{~m}$ asl, oak wood, pH 5.8-6.4 (project EcoFINDERS); leg. R.M. Schmelz, 19.V.2012. Further 7 specimens from same locality, not preserved.

Portugal: One specimen, juvenile: stained whole mount; Olaia, 40.1706; -8.716, 7 m asl, oak wood on a small hill in flood plain near the coast, soil type and $\mathrm{pH}$ unknown; leg. R.M. Schmelz, 18.V.2014. Four further specimens from same locality, not preserved.

Diagnosis. Very small enchytraeids, adults $c a$. 1.5-2 mm long in vivo, 17-19 segments, chaetal formula $2,0-(0), 1: 2-2$, chaetae absent laterally from VI to XII-XV; from XIII-XVI on only 1 chaeta per bundle, brain rounded posteriorly, pharyngeal glands united in IV, V, separate and elongate in VI, oesophageal appendages and intestinal diverticula absent, dorsal blood vessel from XI with peristomial anterior bifurcation, one pair preclitellar nephridia at $7 / 8$, clitellum only lateral, male reproductive organs small, spermathecae with ectal gland, non-glandular ectal duct, small ampulla without diverticula, ental ducts united proximally.

Description. Slow body movements. Colour transparently whitish-pale with gut-contents shining through. Body dimensions: length $1.5-1.9 \mathrm{~mm}$ (viv), $1.3-1.45 \mathrm{~mm}$ (fix), juveniles down to 0.5 $\mathrm{mm}$ (viv); diameter 0.05-0.07 mm (viv), fix: 0.060.1 at V, $0.07-0.12$ at XII, $0.06-0.09$ at XV. Holotype (fix): length $1.4 \mathrm{~mm}$, diameter $0.1 \mathrm{~mm}$ at V, $0.1 \mathrm{~mm}$ at XII, $0.07 \mathrm{~mm}$ at XV. Segment number 17-19. Chaetae. Formula 2,0 - (0), 1: $2-$ 2. Laterally two chaetae from II-V, absent from VI to XII-XV; from XIII-XVI on, 1 chaeta per bundle. Ventrally 2 chaetae per bundle, absent in XII. Chaetae straight with weak ental hook, ectally pointed; length range $10-26 \mu \mathrm{m}$, diameter ca. $2 \mu \mathrm{m}$; chaetae shorter anteriorly $(c a .15 \mu \mathrm{m})$ than posteriorly (up to 20-26 $\mu \mathrm{m}$ ), and shorter laterally than ventrally, e.g. (1 specimen): chaetae increasing in size from $10 \mu \mathrm{m}$ (II) to $15 \mu \mathrm{m}(\mathrm{V})$ laterally, and from $16 \mu \mathrm{m}$ (II) to $20 \mu \mathrm{m}$ (V) ventrally. Lateral postclitellar chaetae near clitellum smallest $(10 \mu \mathrm{m})$, caudal ventral chaetae largest $(20-26 \mu \mathrm{m})$. Prostomium short, with thickened frontal epithelium. Head pore not ascertained, probably at 0/I. Epidermal gland cells not seen. Body wall $c a$. 3-4 $\mu \mathrm{m}$ thick, i.e. comparatively thin, cuticle inconspicuous, mostly $<1$ $\mu \mathrm{m}$. Brain rounded posteriorly, extending into III, twice as long as wide. Pharyngeal pad small, almost as high as long, roughly spherical, often below brain. Pharyngeal glands united in IV and $\mathrm{V}$ dorsally, primary ventral lobes in V; glands separate in VI, larger than in IV or V, compact, variable in shape, not separated into dorsal and ventral lobe, often incised halfway. Holotype with postero-dorsal projections and small posteroventral projections into VII. No oesophageal appendages, no intestinal diverticula. Chloragocytes from IV, dense layer from VII, cell diameter ca. $16 \mu \mathrm{m}$, equalling chaetal lengths; vesicles conspicuously greenish-brown, diameter $1-2 \mu \mathrm{m}$, more than twice the diameter of the coelomocyte vesicles. Oesophagus narrow; transition into intestine marked as a spindle-shaped widening, together with a more or less abrupt widening of gut lumen; no canals or furrows distinguished; widening beginning at about $1 / 2 \mathrm{VI}-1 / 2 \mathrm{VII}$; here long cilia in movement observed. Midgut: Pars tumida in XIV-XVI, occupying 1-2 segment lengths; no Cejkaian tubules. Dorsal blood vessel from XI, anterior bifurcation in peristomium. Two pairs of commissural vessels seen in IV; ventral blood vessel from IV on. One pair of preclitellar nephridia, at 7/8. Anteseptale with parts of nephridial body, no constriction at septum, funnel in obliquely upright position, postseptale $c a .2 \mathrm{x}$ as long as anteseptale; efferent duct as a narrowed continuation of postseptale. Windings of canal dense and conspicuous, down to nephridioporus. No terminal vesicles. Postclitellar nephridia in many positions, e.g. at 13/14, 14/15, 15/16, 17/18, paired and unpaired. Coelomocytes one type, mucocytes. Cells flat, almost disc-shaped, slightly longer than wide, length $c a$. $20 \mu \mathrm{m}$, completely and homogeneously filled with small, conspicuous and slightly brownish vesicles, neither opaque not translucent in transmitted light, pro- 


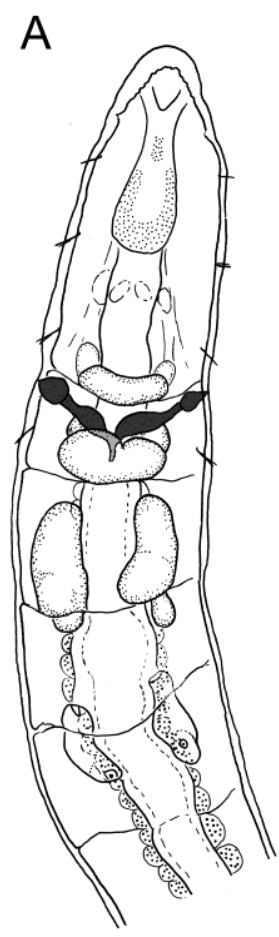

$\mathrm{B}$

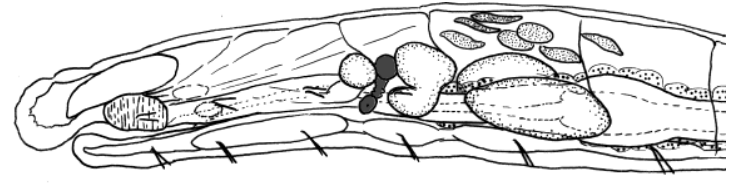

C

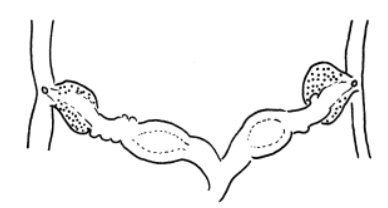

D

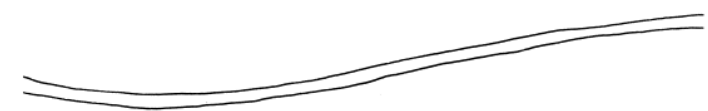

E

$\mathrm{F}$
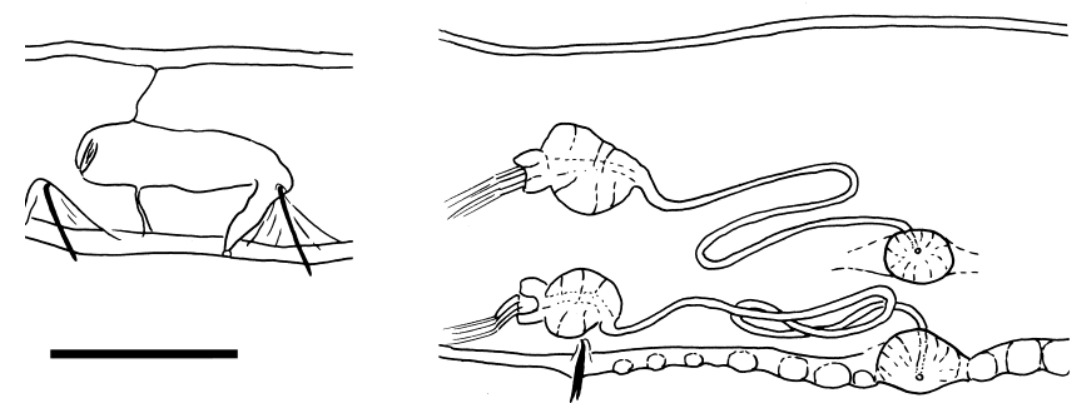

Figure 1. Enchytronia pygmaea sp. nov. A = Anterior end, dorsal view, holotype. Spermathecae shaded grey. Punctation in brain indicate region of perikarya. The pharyngeal pad is hidden below the brain. B = Anterior end, lateral view, paratype. Spermathecae shaded grey. Pharyngeal pad below brain. Coelomocytes shown in VI-VII. C = Spermathecae, dorsal view, holotype.

$\mathrm{D}=$ Clitellum, lateral view, non-type specimen from Sardinia, Italy. E. Preclitellar nephridium, lateral view. $\mathrm{F}=\mathrm{Gonadal}$ region, latero-ventral view. Roman numerals: segments. Scale bar $=100 \mu \mathrm{m}(\mathrm{A}-\mathrm{B}), 50 \mu \mathrm{m}(\mathrm{C}-\mathrm{F})$.

viding a slight tinge of the cell. Vesicles distinctly smaller than chloragocyte vesicles, estimated diameter $0.5 \mu \mathrm{m}$. Cells brownish in vivo, with rose tint in the paracarmine-stained whole mounts. In fixed specimens, cells in oblique position often lemon-shaped, apparently because of flat cell margins.
Clitellum only laterally developed, i.e. absent dorsally and ventrally; dorsal margin one longitudinal cell row above lateral chaetae, ventral margin at level of male pores; longitudinal extension from septum 11/12 to chaetae of XIII; cells in $c a .11$ separate rows; inconspicuous in most specimens; anterior and posterior margins as 
well as cell types not well-distinguished; gland cells about twice as high $(c a .5 \mu \mathrm{m})$ as adjacent epidermis (ca. $2 \mu \mathrm{m})$. When fully developed, up to $12 \mu \mathrm{m}$ high, hyalocytes inflated, granulocytes not distinguishable. Seminal vesicle absent, few cysts dorsally in XI. Spermatozoa ca. $30 \mu \mathrm{m}$ long, heads $12-15 \mu \mathrm{m}$ long. Sperm funnel small, length ca. $40 \mu \mathrm{m}$, less than $1 / 2$ body diameter, collar conspicuous, about as high as wide $(15 \mu \mathrm{m})$, funnel body flattened, about as wide as long, maximum diameter equalling length ( $c a .25 \mu \mathrm{m})$, minimum diameter almost equalling collar diameter. Vas deferens comparatively short, in 12 wide loops, diameter $c a .5 \mu \mathrm{m}$, estimated length $2 \mathrm{x}$ body diameter. Male pore surrounded by a small lens-shaped gland, about twice as high as body wall, length $25 \mu \mathrm{m}, c a .1 .5 \mathrm{x}$ as long as wide or high. Male pores apparently on body surface, no bursa or bursal slits distinguished. No subneural glands. Spermathecae united middorsally, ectal gland rounded, sessile, diameter $c a$. $15 \mu \mathrm{m}$; ectal duct half as wide as ectal gland, 1$2 \mathrm{x}$ as long as ampulla (depending on state of contraction), not glandular but outline wavy due to adhering cell nuclei, ampulla inconspicuous, spherical or ellipsoid, diameter $c a .11 \mu \mathrm{m}$, sperm not distinguished in living and preserved specimens. Ental ducts shorter than ectal ducts, uniting mid-dorsally. One large egg at a time, occupying more than 1 segment length.
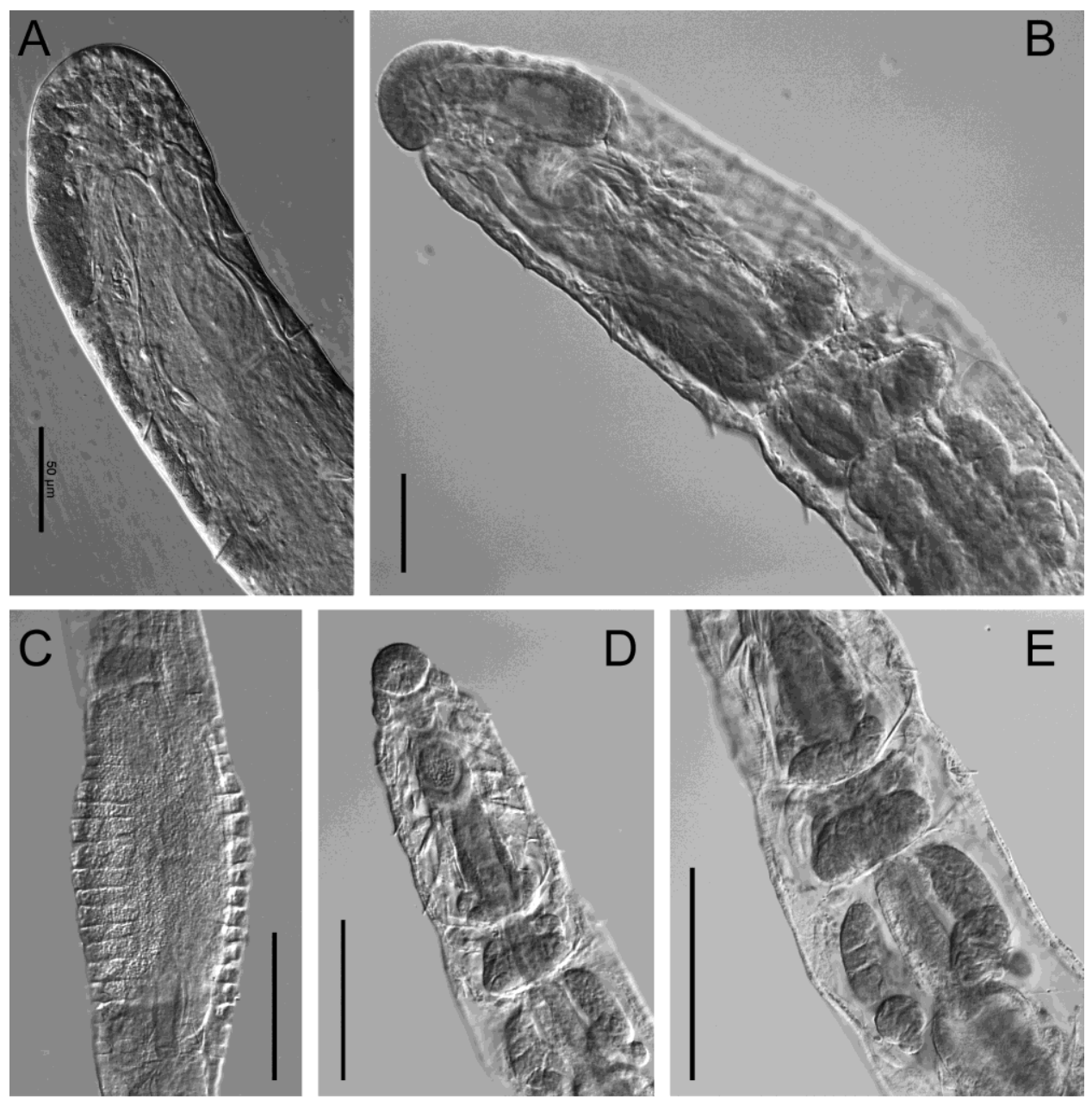

Figure 2. Enchytronia pygmaea sp. nov. A = Anterior body region, dorsal view, living non-type specimen from type locality, strongly flattened to show peristomial bifurcation of dorsal blood vessel. $\mathrm{B}=$ Anterior body region, latero-dorsal view, paratype. $\mathrm{C}=$ Clitellar region, dorso-lateral view, paratype. $\mathrm{D}=$ Anterior body region, ventral view, holotype. $\mathrm{E}=$ Anterior body region, ventral view, focusing plane in dorsal body region, holotype. 


\section{DISCUSSION}

\section{Species comparison and generic placement}

We place this species in the genus Enchytronia Nielsen \& Christensen, 1959, because of the shape and arrangement of chaetae lacking laterally in a number of preclitellar segments, the peristomial bifurcation of the dorsal blood vessel, the overall shape of the spermathecae, and the only laterally developed clitellum. It disagrees with the generic diagnosis - and with all species included in this genus so far - by the posteriorly rounded brain (incised in the other species), the presence of only one lateral chaeta in postclitellar positions ( 2 in the other species), and in the presence of only one pair of preclitellar nephridia.

As an alternative, the new species could be placed in Marionina Michaelsen, 1890, sensu auctorum. However, Marionina is a heterogeneous and polyphyletic assemblage of species (Rota et al. 2008, Schmelz \& Collado 2008). Furthermore, the new species is much more similar to the type species of Enchytronia (Enchytronia parva Nielsen \& Christensen, 1959) than to the type species of Marionina (Pachydrilus georgianus Michaelsen, 1888) considering morphology, distribution and habitat: Enchytronia parva is a small mineral soil dweller with palearctic distribution; it has a maximum of two, distally straight chaetae per bundle, chaetae often missing laterally in some segments before clitellum, the nephridial anteseptale is with coils of canal, and spermathecae are fused entally. Marionina georgiana, on the other hand, is a marine littoral subantarctic species with up to 6 (or even 7) sigmoid chaetae per bundle in asymmetric fan-shaped arrangement, all positions occupied; the nephridial anteseptale consists of the funnel only, and spermathecae are separate entally (Rota et al. 2008, Schmelz \& Collado 2008).

From the remarks above it is obvious that the new species has to be compared with species of Enchytronia and Marionina. The pattern of chaetae is unique in Enchytraeidae, and few spe- cies are as small as or even smaller than $E$. pygmaea. The most apparent attribute of the new species is the presence of lateral chaetae in only 4 preclitellar segments, from II-V, a character shared by Marionina minutissima Healy, 1975, and Enchytronia oligosetosa Sesma \& DózsaFarkas, 1993, two species of likewise small body size. However, M. minutissima is distinguished from the new species by the absence of lateral postclitellar chaetae, a posteriorly incised brain and the presence of yellow-brown epidermal glands on each segment. E. oligosetosa differs in having 2 chaetae per bundle laterally in postclitellar segments and a pair of lateral intestinal diverticula in VI. The number of preclitellar nephridia is not explicitly described in either species. Marionina clavata Nielsen \& Christensen, 1961 has a similar chaetal formula: 2,0-1:2-2, but lateral preclitellar chaetae are present in 7 segments, from II to VIII, and not in 4, from II to $\mathrm{V}$, as in E. pygmaea. Further differences from the new species are a pair of oesophageal appendages in IV, dorsally developed clitellum, and a posteriorly incised brain, among other characters. The presence in E. pygmaea of only one pair of preclitellar nephridia is unique among species of Enchytronia and Marionina, but this character is unknown in many species of these two genera. It is known, however, in the two other similarly small enchytraeid species known to-date: M. eleonorae Rota, 1995 (15-17 segments, body length 0.9-1.4 mm) and M. deminuta Rota, 2013 (16-21 segments, $0.9-1.4 \mathrm{~mm}$ ) have preclitellar nephridia at $7 / 8$ and $8 / 9$; furthermore, they differ from the new species in the presence of two chaetae in all lateral postclitellar bundles, among many other characters.

In general, E. pygmaea is most easily identified because of the unique chaetal pattern, which shows up well even in fixed material. Among the preserved specimens, only those from Italy have lateral postclitellar chaetae throughout from XIII, in all other specimens, the holotype included, some postclitellar segments are without lateral chaetae. However, the state of this character is unknown in the specimens that were investigated only in vivo. 


\section{Distribution and habitat}

(Figure 3)

Up to now, E. pygmaea was found in Germany, Denmark, The Netherlands, France, Portugal, Italy, and Estonia. The distribution of the new species can hence be characterized as widespread in Europe. The species is a mineral soil dweller and seems to prefer sandy soils without restriction to a specific land-use type (forest, grassland, arable land). In terms of humus forms the known locations can be classified as
Mull sites ranging from moderately to slightly acid soil conditions (Graefe \& Schmelz 1999). It was often but not exclusively found in deeper strata (below $5 \mathrm{~cm}$ from surface), similar to Enchytronia parva. It was abundant at the type locality and at the Netherlands sites; these are all extensively used grassland sites.

Acknowledgments - The second authors thanks numerous workers who took soil samples in the framework of different projects, notably the European-funded EcoFINDERS project and the German-funded Edaphobase project.

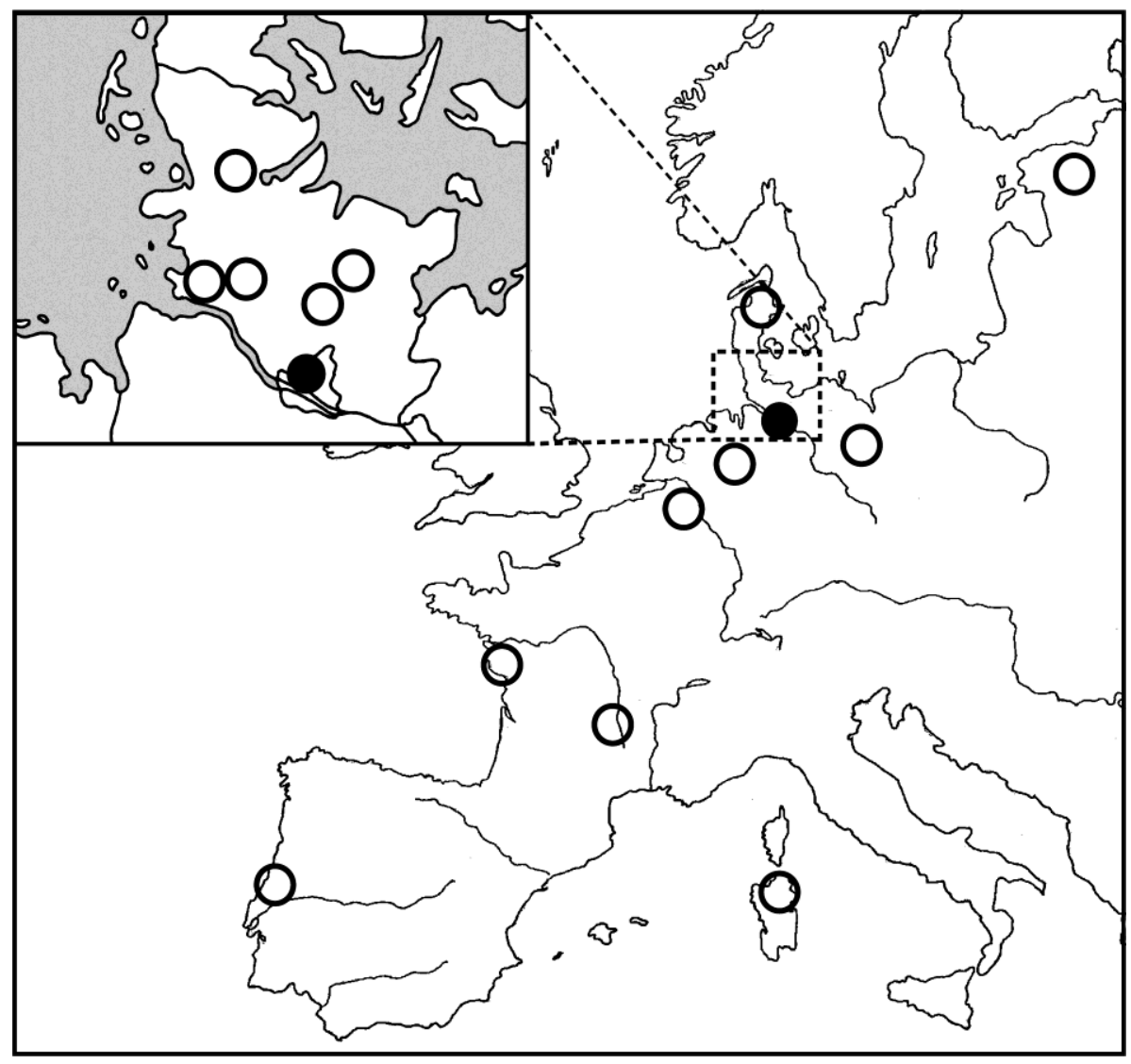

Figure 3. Localities with finds of Enchytronia pygmaea sp. nov. in Europe, and especially Schleswig-Holstein (top left). The type locality (filled circle) is shown twice.

\section{REFERENCES}

GRAEFE, U. \& SCHMELZ, R.M. (1999): Indicator values, strategy types and life forms of terrestrial Enchytraeidae and other microannelids. In. SCHMELZ, R.M. \& SÜHLO K. (Ed.) Newsletter on Enchyt- raeidae No. 6. Proceedings of the 3rd International Symposium on Enchytraeidae, Osnabrück, Germany, Universitätsverlag Rasch, Osnabrück, Germany, p. 59-67.

HeALy, B. (1975): A description of five new species of Enchytraeidae (Oligochaeta) from Ireland. Zoolo- 
gical Journal of the Linnean Society, 56: 315-326. doi: 10.1111/j.1096-3642.1975.tb00273.x

MiChAELSEN, W. (1888): Die Oligochaeten von SüdGeorgien. Jahrbuch der Hamburgischen Wissenschaftlichen Anstalten, 4-5: 55-73.

Nielsen, C.O. \& Christensen, B. (1959): The Enchytraeidae. Critical revision and taxonomy of European species (Studies on Enchytraeidae VII). Natura Jutlandica, 8-9: 1-160.

Nielsen, C.O. \& Christensen, B. (1961): The Enchytraeidae. Critical revision and taxonomy of European species. Supplement 1. Natura Jutlandica, 10: 1-23.

RoTA, E. (1995): Italian Enchytraeidae (Oligochaeta). I. Bollettino di Zoologia, 62: 183-231. doi: 10.1080/11250009509356067

Rota, E., Matamoros, L. \& Erséus, C. (2008): In search of Marionina (Clitellata, Enchytraeidae): A taxonomic history of the genus and re-description of the type species Pachydrilus georgianus Michaelsen, 1888. Italian Journal of Zoology, 75: 1-20. doi: 10.1080/11250000801930433

SchMElz, R.M. \& Collado, R. (2008): A type-based redescription of Pachydrilus georgianus Michaelsen, 1888 , the type species of Marionina Michaelsen, 1890, with comments on Christensenidrilus Dózsa-Farkas \& Convey, 1997 (Enchytraeidae, "Oligochaeta", Annelida). Verhandlungen des $\mathrm{Na}$ turwissenschaftlichen Vereins in Hamburg (Neue Folge), 44: 7-22.

Schmelz, R.M. \& Collado, R. (2010): A guide to European terrestrial and freshwater species of Enchytraeidae (Oligochaeta). Soil Organisms, 82: 1-176.

SESMA, V. \& DÓZSA-FARKAS, K. (1993): Description of seven new species of Enchytraeidae (Oligochaeta) from Spain. Acta Zoologica Hungarica, 39: 249-265. 